\title{
Mangroves and Their Response to a Heavy Metal Polluted Wetland in The North Coast of Puerto Rico
}

Marixa Maldonado-Román ${ }^{1^{*}}$, Johannys Jiménez-Collazo ${ }^{1}$, Karlo Malavé-Llamas ${ }^{2}$, Juan Carlos Musa-Wasill ${ }^{1}$

\author{
${ }^{1}$ School of Environmental Affairs, Universidad Metropolitana, San Juan, Puerto Rico \\ ${ }^{2}$ School of Science and Technology, Universidad Del Este, URGREAT-MBRS-RISE-NIH, Carolina, Puerto Rico
}

\begin{abstract}
Peninsula La Esperanza is part of the San Juan Bay Estuary and located in the north coast of Puerto Rico. Mangroves are the predominant type of vegetation; that can exhibit diverse external and internal mechanisms allowing them to tolerate and to act as phytoremediators of heavy metals (HM) in surrounding soils. This study was focused in three mangrove species that can be found in La Esperanza: Rhizophora mangle (RM), Laguncularia racemosa (LR) and Avicennia germinans (AG). Arsenic (As), cadmium (Cd), chromium (Cr), copper $(\mathrm{Cu})$, mercury $(\mathrm{Hg})$, lead $(\mathrm{Pb})$, and zinc $(\mathrm{Zn})$ were selected to be identified, measure concentrations in sediments, in green (GL) and senescent (SL) leaves, and study phytoremediation potential as a mitigation alternative calculating bioconcentration afctors (BCFs) and retranslocation percents (RT\%). For this, Peninsula La Esperanza was divided in three main research sites. Our results show a significant difference among all heavy metals and their distribution in each site. Moreover, the mangrove species, A. germinans, showed lower RT\% for $\mathrm{Hg}$ in all three sites, which could be considered the best species for phytoextraction of this heavy metal. The results suggest that the three species have a synergistic effect in the way they manage the heavy metal in surrounding polluted soils, although each species have a different capacity to manage each heavy metal.
\end{abstract}

Keywords: Mangroves, Bioconcentration, Retranslocation, Heavy Metals, Phytoremediation

\section{INTRODUCTION}

Peninsula La Esperanza is located in the North region of the main island of Puerto Rico (coordinates $18^{\circ} 27^{\prime} 06.28^{\prime \prime} \mathrm{N}, 66^{\circ} 08^{\prime} 07.09^{\prime} \mathrm{W}$ ) (Figure 1) [1]. It is part of the Las Cucharillas Marsh Natural Reserve (CMNR) and the San Juan Bay Estuary Watershed (SJBE) (Figure 2). The SJBE is considered a unique tropical estuary for the National Estuary Program of the US Environmental Protection Agency (USEPA). Since 1979, the Puerto Rico Department of Natural and Environmental Resources (DNER), designated Las Cucharillas marsh as a wildlife reserve, however, in 2008 was changed to Natural Reserve. The complete marsh has about 1,236 acres (500 hectares) that serve as permanent habitat for many species of marine birds,

${ }^{*}$ Corresponding author:

Marixa Maldonado-Román

School of Environmental Affairs, Universidad Metropolitana 1399, Avenida Ana G. Mendez, San Juan 00926, Puerto Rico E-mail address: m.maldonado04@gmail.com

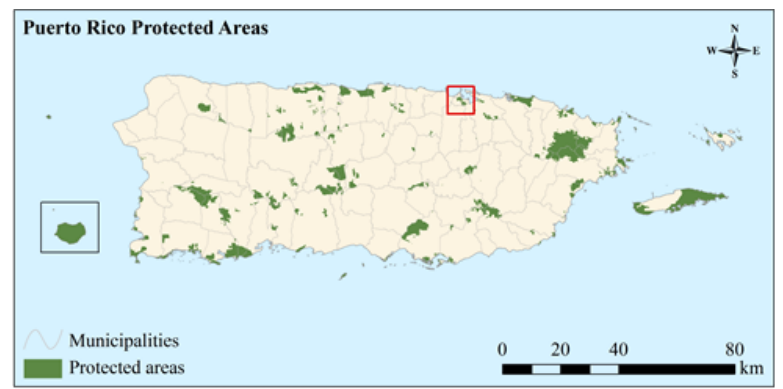

Figure 1. Protected natural areas of Puerto Rico [1]

and a transitory habitat for migratory birds; including 7 species that are considered endangered or vulnerable like the Fulica caribaea (Caribbean coot) and the Charadrius melodus (Piping plover) [2].

\section{How to cite:}

Maldonado-Román M, Jiménez-Collazo J, Malavé-Llamas K, Musa-Wasill JC (2016) Mangroves and Their Response to a Heavy Metal Polluted Wetland in The North Coast of Puerto Rico. J. Trop. Life. Science 6 (3): 210 -218. 


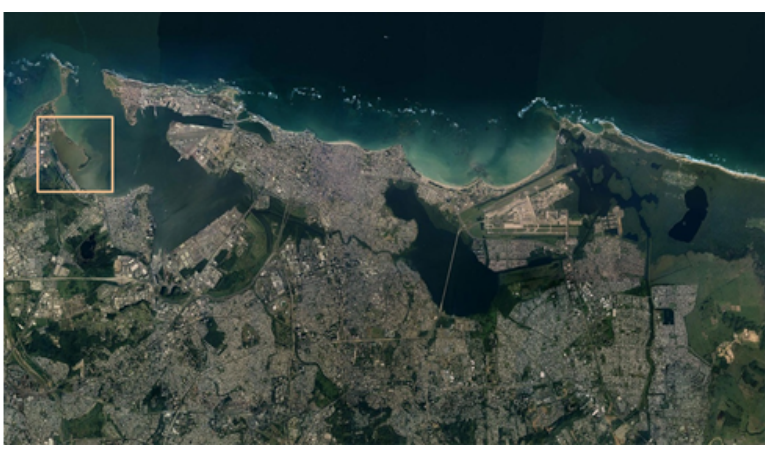

Figure 2. San Juan bay estuary watershed

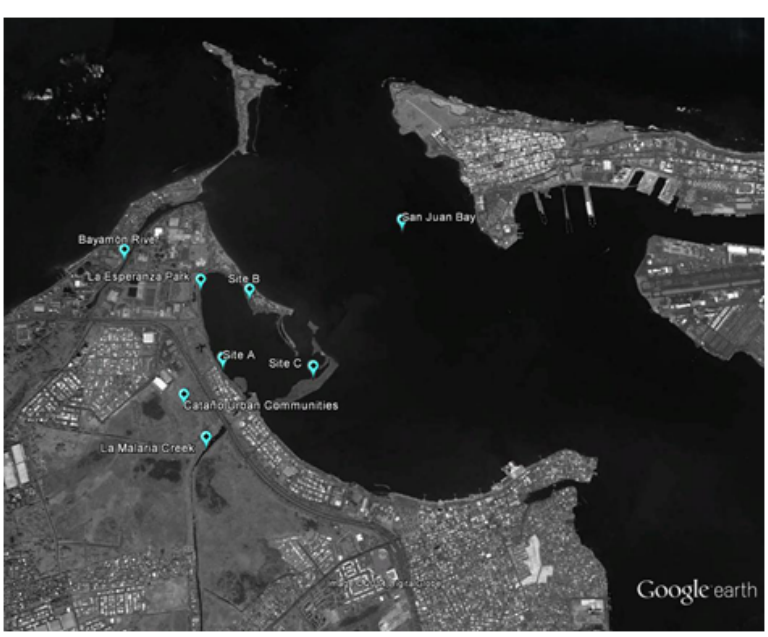

Figure 3. Peninsula La Esperanza

Other species use the marsh as feeding sites during the night, giving an example of connectivity with other inland ecosystems, such is the case of the Noctilio leporinus (or fishing bat) [3]. Peninsula La Esperanza serves as host of two small fishing communities and is part of the main entrance for many tourist and cargo ships. As it is the case of many others estuaries around the world, the CMNR has been severely impacted by human actions through the years. It has been used and changed in many forms: as a clandestine dumpsite; the pattern of one of its main affluent rivers (Bayamon River) was changed, and surrounded by oil refineries and other industries. All of these events have significantly reduced the wetland area, leaving just a small amount of natural areas in the middle of the urban sprawl. The peculiar form of the area is a result of different events of dredge and fill that created a peninsular type of pattern (Figure 3 ).

The border of the Península La Esperanza has a predominant vegetation of three species of mangroves: Rhyzhophora mangle (red mangrove), Laguncularia racemosa (white mangrove) and Avicennia germinans (black mangrove). In tropical regions, mangroves are one of the main protectors of the coastal fringe, they prevent coastal erosion, act as buffer of protection against hurricanes, and wave energy impacts [4]. This ecosystem can also provide many services to local communities; including sources of food, raw materials, medicinal resources, flood and climate regulation, tourism and recreation, education, among others [5]. Also, for the field of bioremediation, mangroves can be used as phytoremediators. Phytoremediation is the ability of a plant such as mangroves to absorb several pollutants, like heavy metals (HM), from surrounding sediments and also to serve as bioindicators for HM pollution $[17,18,19]$. This technique seems to be a cost effective way to restrain heavy metals within an area. Several aquatic plants have been studied for their capacity to accumulate heavy metals in different parts of their organism (shoot, stem, roots, and leaves) [12, 13]. However, is when bioaccumulation on the leaves occur [20] that there could be a higher chance of transporting heavy metals to the surrounding environment.

Plants used several mechanisms to restrain pollutants such as HM in their parts; in this study we assess retranslocation and bioconcentration mechanisms. Translocation is the ability of the plant to move nutrients from one part of the plant to another, usually measures the movement of ions from root to the leaves. This concept can be applied to heavy metals, since they can bound to sediments [15], be absorbed by the roots and cause changes in the plant structure [22, 23]. Retranslocation measures how much the tree is reusing, when the root concentrations are not available [24]. Therefore, we adapt the formula used to measure Phosphorus, Potassium and Nitrogen known as the Nutrient Reabsorption Efficiency and we used it to measure heavy metal retranslocation percent (RT \%) using the heavy metal concentrations found in senescent and green leaves of the three mangrove species. In the other hand, Bioconcentration is a process where the chemical concentration in an organism achieves or exceeds the levels found in their surrounding medium [8]. To measure bioconcentration of HM on mangroves leaves we used the bioconcentration factor (BCF). The BCF is defined as the concentration ratio of HM in an organism tissue divided by the HM concentration in an environmental matrix (water, soil or sediment) [14].

Previous research efforts have demonstrated significant concentrations of heavy metals on the marsh [9]. Our study will assess the concentrations of eight heavy metals (lead $(\mathrm{Pb})$, mercury $(\mathrm{Hg})$, cadmium $(\mathrm{Cd})$, arsenic (As), selenium (Se), copper $(\mathrm{Cu})$, chromium 
$(\mathrm{Cr})$, zinc $(\mathrm{Zn})$ from Peninsula La Esperanza. Soil metal concentration in the natural environment mainly depend on geological and mineralogical characteristics of the parent material, whereas in the urban environment it is also affected by dry and wet deposition of metals emitted by human activities or transported from the surroundings [7]. Copper and Zinc are considered essential mineral elements but could be toxic in high levels [10]; while Lead, Mercury, Cadmium, Arsenic and Chromium are non-essential/toxic heavy metals [11]. One particular case is Mercury, which can be transformed into Methyl-Mercury, a persistent metabolite of highest concerns for public health, due to their bioavailability for organisms to uptake with more chances to enter in the trophic chain [21].

The main purpose of this study was to assess the levels of $\mathrm{Pb}, \mathrm{Hg}, \mathrm{Cd}, \mathrm{As}, \mathrm{Se}, \mathrm{Cu}, \mathrm{Cr}, \mathrm{Zn}$ in the mangrove sediments and mangrove leaves to compare the phytoremediation potential of each species by measuring BCF and RT percents in $R$. mangle, A. germinans, and $L$. racemosa.

\section{MATERIALS AND METHODS}

For our study we have divided La Esperanza in three study sites (Figure 4). The site A is located in an urbanized area and closer to La Malaria Creek, site B is located within a recreational park, and site $\mathrm{C}$ know as Esperanza Isle, where the main population of mangroves is located. Because of logistics reasons we started the sampling in site $\mathrm{C}$ because it was more distant and more challenging to sample, since it is only accessible by boat; following with site $\mathrm{B}$, and finally site A. Figure 4 shows a distribution of all sediment samples collected using Garmin $72 \mathrm{H}$. These were only taken where mangrove vegetation was present. Site $C$ has an abundant population of Australian pine (C. equisetifolia) on the east side of the isle, there were no samples collected in that part.

\section{Sediment samples}

Sediment samples were taken using a $\mathrm{T}$ shape stainless steel tool. This tool collects sediments from the first 15 centimeters of the soil. The first 5 inches were discarded to avoid contamination of the sample with detritus material. The samples were stored in sterilized glass containers and maintained in a cooler until they were taken to an EPA licensed laboratory in Puerto Rico. A total of 40 samples were collected along the Peninsula. Taking in consideration the size of each of the three areas of study, we collected 8 samples in site A, 8 samples in site B, and 24 samples in site C.

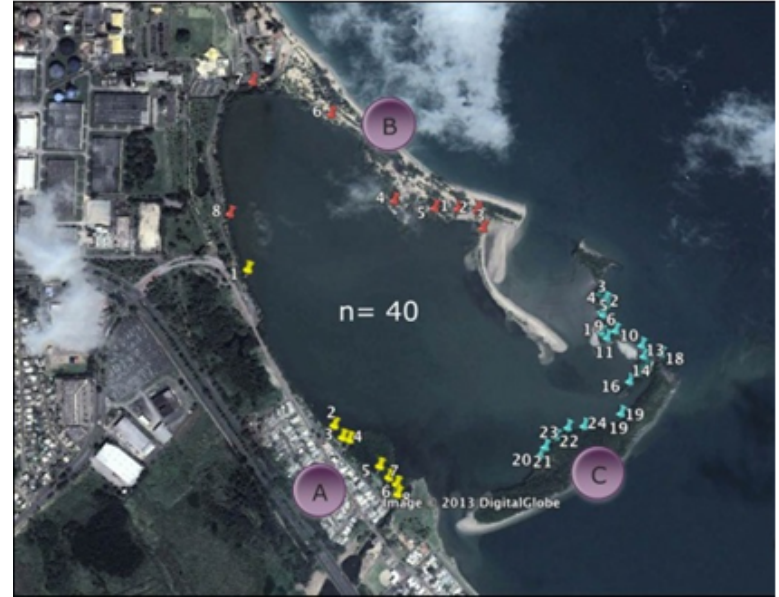

Figure 4. Distribution of sediment samples for sites A, B and C.

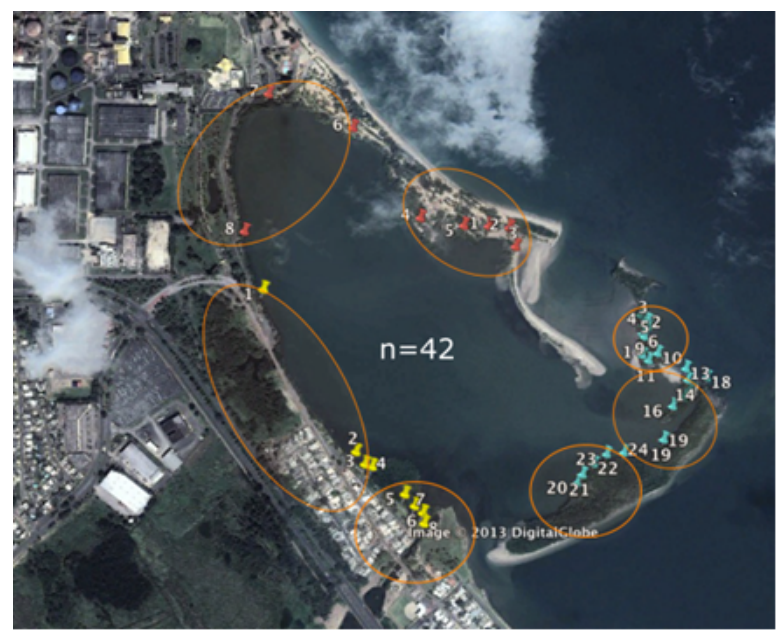

Figure 5. Mangrove leaves sampling areas

The method used by the laboratory for the analysis of the sediments was the EPA $6010 \mathrm{C}$ for all the heavy metals, except for Mercury which requires the process EPA 7471B (Cold-vapor atomic absorption). Both methods used the ICP (inductively coupled plasmaatomic emission spectrometry) technology.

\section{Leaves samples}

Green (GL) and senescent leaves (SL) were collected randomly (Figure 5) from young and mature mangrove trees of each one of the three mangrove species of interest. The leaves were identified and stored, until they were taken to an EPA certified laboratory. A total of 42 samples (21 green leaves samples and 21 senescent leaves samples) were collected along the Peninsula's coastline.

\section{Empirical equations}

Two empirical equation were used to analyzed the 
data. The RT\% was used to measure the HM absorption percent between senescent leaves and green leaves. The BCF's measured the HM concentration from soil into leave tissue and their bioconcentration ratio [12, $13]$.

$$
\begin{gathered}
\% R T=\left(1-\frac{[\text { HM senescent }]}{[\text { HMreen }]}\right) \times 100 \\
B C F=\left(\frac{\text { HM leaves }}{\text { HM soil }}\right)
\end{gathered}
$$

\section{Statistical analysis}

The One Way Anova statistical analysis was performed using the MiniTab-14 program.

\section{RESULTS AND DISCUSSION}

Our sediment sample analysis showed (Figure 6) that $\mathrm{Zn}, \mathrm{Hg}, \mathrm{Pb}, \mathrm{Cu}, \mathrm{Cr}, \mathrm{Cd}$ were more abundant in site A than in the other two sites at La Esperanza. Arsenic was the only one found in higher concentrations for the site $\mathrm{C}$. When taking in consideration the mean concentrations of each heavy metal in all sites, the amounts from high to low showed a pattern of: $\mathrm{Zn}>$ $\mathrm{Cu}>\mathrm{Cr}>\mathrm{Pb}>\mathrm{As}>\mathrm{Cd}>\mathrm{Hg}$. Selenium was not detected in any of our samples, therefore is not included for analysis. Mercury was found at low concentrations compared to the other metals tested, but in higher concentrations for site A, which could be strongly linked to anthropogenic factors, and to the factor of water currents.

The anthropogenic factors that can be linked to the higher concentration of Mercury for site A, could be due to La Malaria creek upstream sources such as combustion and industrial discharges from thermoelectrical refineries and several industrial nearby.

At the present, Puerto Rico lacks of baseline for most kind of its soils. Our research is exploratory in these soils. Due to similarities in origin and sand composition to Florida soils and the scarcity of trace metal baseline for the island, we adopted as reference for our study the baseline of trace metal for Florida [25]. Results for sediment samples demonstrated that when comparing the distribution of each metal among the three sites, all the $\mathrm{p}$ values were $\leq 0.05$. We obtained, for As a $\mathrm{p}$ value of $\leq 0.045$, for $\mathrm{Cd}$ a $\mathrm{p}$ value $\leq 0.021$, and for all other metals $\mathrm{p}$ values of $\leq 0.000$.

This shows that the distribution of each heavy metal among the three sites is significantly different from each other. When the distribution of all metals within a sampling site was compared, we obtained $p$ values of $\leq 0.000$. Some possible factors for this could be: rates of deposition of the heavy metal ions in sedi-

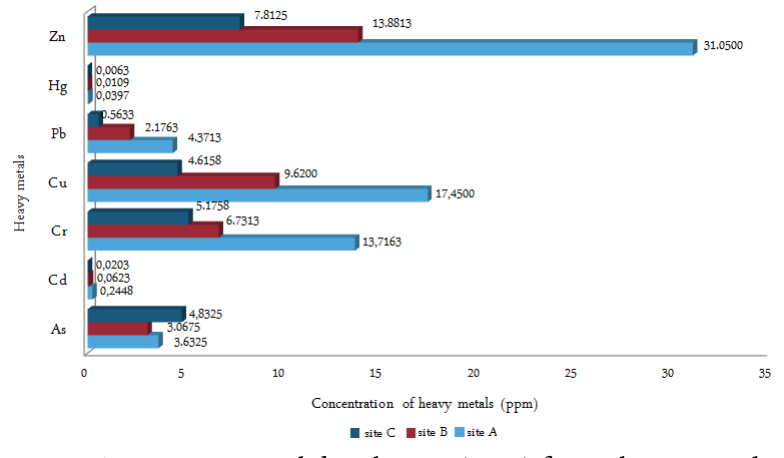

Figure 6. Heavy metal distribution ( $\mathrm{ppm}$ ) for each site sample (A, B and C)

ments, distribution of vegetation in La Esperanza, the rate of bio-absorption of ions, bio-availability of ions in sediments, among other factors. Site A has a $\mathrm{Hg}$ mean concentration of 0.040 which is at the level of the maximum concentration found for FL (0.0396 ppm) for that metal. In this same site $\mathrm{Zn}$ has concentrations of $31 \mathrm{ppm}$, while the maximum for the FL study [25] was $29.6 \mathrm{ppm}$. Pb is other heavy metal of concern for public health and shows higher values in soils near the urbanized sites A and B (Figure 6).

Results obtained from the Green (GL) and Senescent Leaves (SL) were used to calculate Bioconcentration Factors (BCF's) can give some information of presence of heavy metals that Rhyzhophora, Laguncularia and Avicennia might be uptaking from soils and transporting through their systems, until it reaches the leaves. For Site A (Figure 7): $\mathrm{As}, \mathrm{Cr}, \mathrm{Cu}, \mathrm{Pb}$, and $\mathrm{Zn}$ were 0.2 or below; $\mathrm{Hg}$ values were 0.8 and below; $\mathrm{Cd}$ were 1.8 or below. For Site B (Figure 8): As, Cr, $\mathrm{Cu}$, $\mathrm{Pb}$, and $\mathrm{Zn}$ were below 1.0; $\mathrm{Hg}$ were below 3.0; and $\mathrm{Cd}$ were below 7.0. For Site C (Figure 9): $\mathrm{As}, \mathrm{Cr}, \mathrm{Cu}$, $\mathrm{Pb}, \mathrm{Hg}$, and $\mathrm{Zn}$ were below 5.0; and $\mathrm{Cd}$ were below 30.

A comprehensive study made on the San Juan Bay Estuary (SJBE) analyzed 13 trace metals, organic chlorine pesticides and PAH's in bottom sediments and biotic-tissues at 19 points in the estuary. The results were compared with threshold effects level (TEL) and probable effects level (PEL) for each metal. The results indicated that the western portion of the Estuary (Peninsula La Esperanza) had the highest concentrations (ppm) of $\mathrm{Cu}(53.9,47.9,39.8)$ As $(23.5,15.0,17.7) \mathrm{Zn}$ $(40.2,81.3,87.6)$ and $\mathrm{Hg}(0.22,0.21,0.36)$ in sediments. The concentrations of $\mathrm{As}, \mathrm{Cu}, \mathrm{Se}, \mathrm{Zn}$ and $\mathrm{Hg}$ were detected in most fish and crab's tissues samples. As concentrations exceeded EPA 10-5 cancer risk threshold in the 19 points at the estuary [16]. This research concluded that the study of mangroves in the 


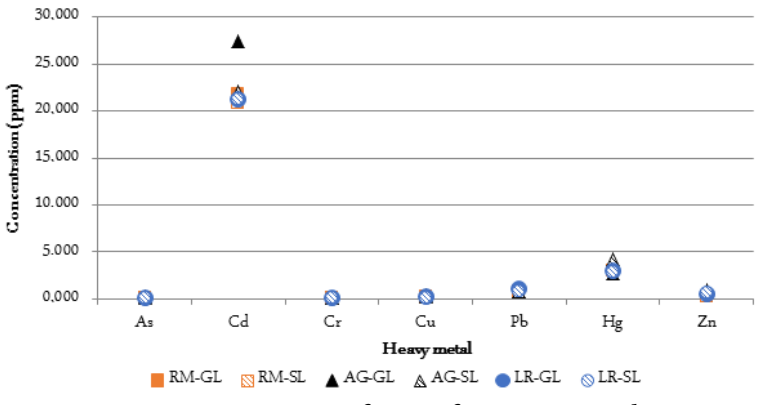

Figure 7. Bioconcentration factors from green and senescent leaves for site $\mathrm{A}$

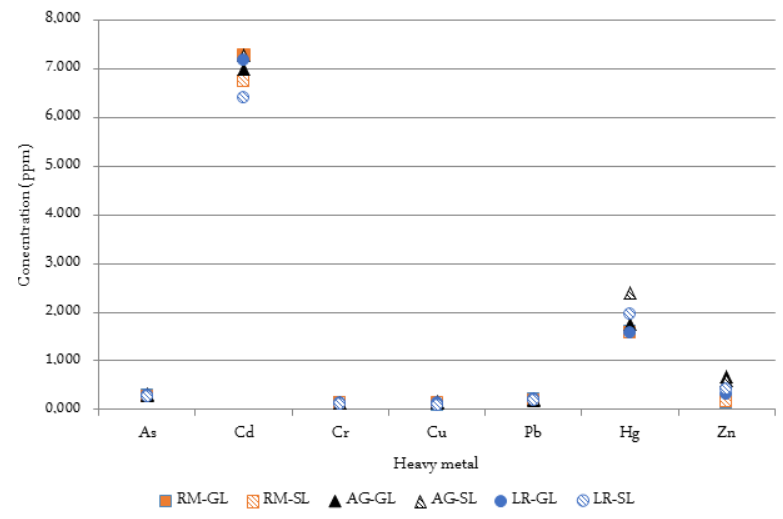

Figure 8. Bioconcentration factors from Green and senescent leaves for site $B$

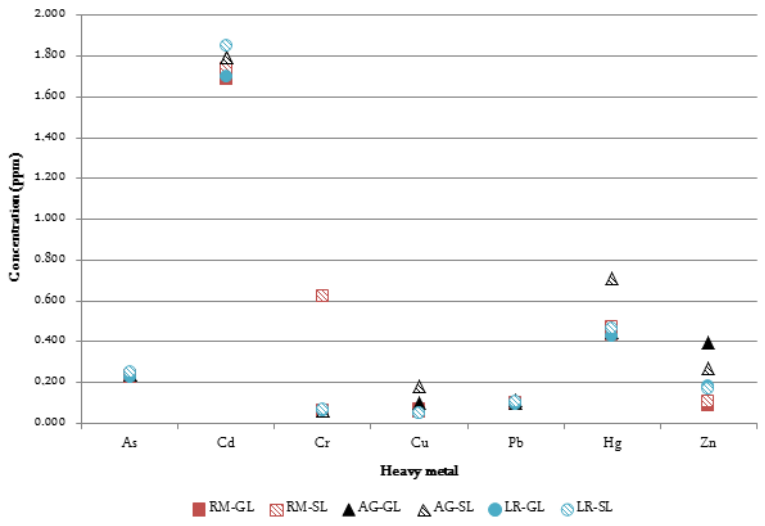

Figure 9. Bioconcentration factors from green and senescent leaves for site $\mathrm{C}$

Estuary offer an excellent opportunity to assess the phytoremediation role on trace metals by this kind of forests. Based on this comment, we conducted our mangrove phytoremediation preliminary assesment at La Esperanza Peninsula, SJBE. Since the BCF is a measure of the amount of metal in leaves compared to the amount in the sediment; results in Figures 7, 8 and 9 showed that Bioconcentration is more for the three species if there is less amount of pollutants in sediments. Since we are only measuring the amount in the leaves we cannot be certain about the amounts of metal that could be deposited near the roots outside the plant (root-sediment interface) or inside the roots of each tree, and what other mechanisms could be playing a role in these aspects.

Same pattern is shown with the three species with $\mathrm{Hg}$. $\mathrm{Hg}$ is a metal very easily bio-available for biota but apparently highly intolerable. If we consider Figures 7, 8 and 9, and compare the values for senescent or yellow leaves with the green leaves for $\mathrm{Hg}$ and $\mathrm{Pb}$, results showed that $A$. germinans has higher BCFs in senescent leaves. A. germinans appears to be the best phytoextractor for $\mathrm{Pb}$ and $\mathrm{Hg}$ under these soil conditions. In the One Way Anova analysis for the BCFs, the three different sampling sites where compared with each metal and each mangrove species and there was not significant difference found for this comparison.

$\mathrm{RT} \%$ are measured as a unit to confirm the results obtained from BCF's values and can give us a broader scope on how the mangroves are behaving in each one of the sites sampled. A positive RT percent represent that the tree could be moving the ions through the plant, while a more negative RT percent value could be interpreted as the plant excreting those ions through the senescent leaves. For Site A (Figure 10) RT \% showed positive values in $R$. mangle for $\mathrm{Cu}$, and $A$. germinans and $L$. racemosa for $\mathrm{Zn}$. Negative values were observed for $A$. germinans for $\mathrm{Cu}$ and $\mathrm{Hg}$. For the Site B; $R$. mangle and $L$. racemosa showed positive values for $\mathrm{As}, \mathrm{Cd}, \mathrm{Cr}$, and $\mathrm{Pb}$. Negative values were observed in $A$. germinans for $\mathrm{As}, \mathrm{Pb}$, and $\mathrm{Hg}$; L. racemosa showed negative values for $\mathrm{Hg}$ and $\mathrm{Zn}$, and $R$. mangle for $\mathrm{Zn}$. For the Site C; results showed positive values for $R$. mangle for $\mathrm{As}, \mathrm{Cd}, \mathrm{Cu}, \mathrm{Pb}$; for $L$. racemosa for metals $\mathrm{Cu}$ and $\mathrm{Pb}$, and for A. germinans for $\mathrm{Cd}, \mathrm{Cu}$, and $\mathrm{Zn}$. Negative values were found for $L$. racemosa for $\mathrm{As}$ and $\mathrm{Zn}$, and for $A$. germinans for As and $\mathrm{Hg}$.

In La Esperanza, A. germinans showed negative RT values (Figure 10) for all sites sampled for $\mathrm{Hg}$ compared to the other two species. Most of the movement of ions seems to occur for $\mathrm{Cu}$ and $\mathrm{Zn}$, which can be linked to what the plant use for enzymatic processes, but there are differences in RT \% since the available ions are very different for the three sites. In the One Way Anova for RT values, when comparing all species and all metals in the three sites, the $\mathrm{p}$ value obtained was 0 , which can be interpreted as a synergistic effect of all species managing all the heavy metals assessed.

$R$. mangle (red mangrove) - is a salt excluding [26] and ion exclusion species [27]. Through the mecha- 


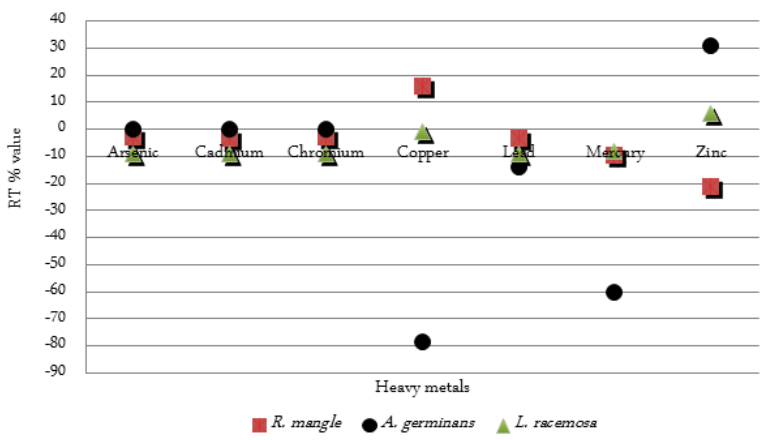

(a)

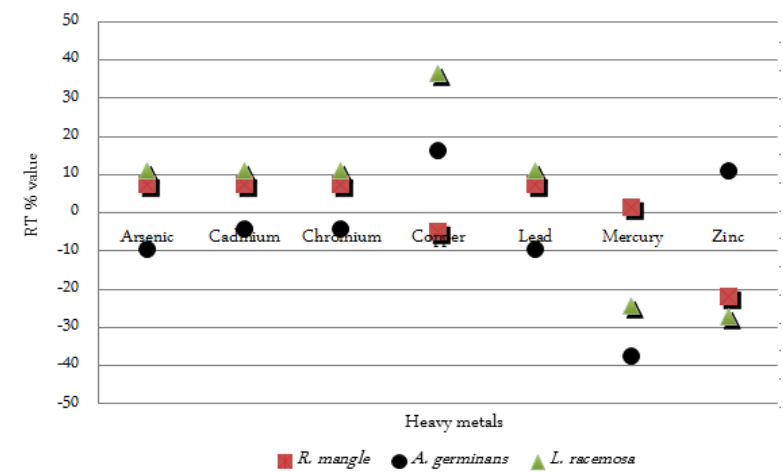

(b)

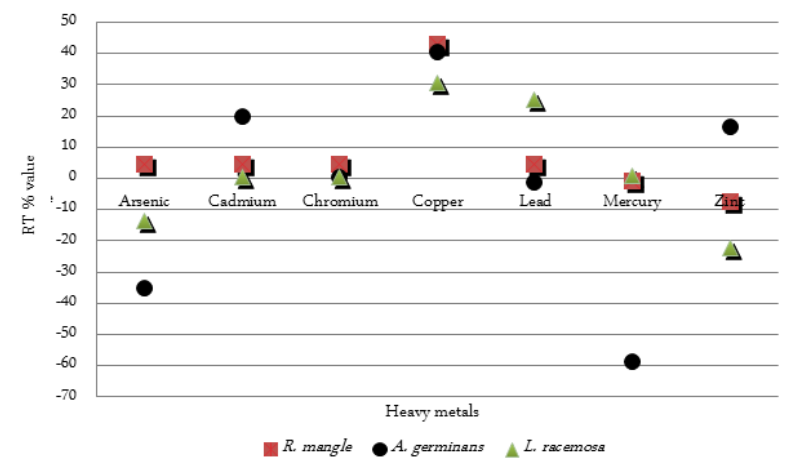

(c)

Figure 10. RT percent values for site A (a), B (b) and C (c) per mangrove species

nisms of iron plaques $[22,28]$ the plant can avoid the entrance of trace metals in the roots. It accumulates the heavy metals in the sediment- root interface or in the root tissue. Considering the decomposition of $R$. mangle leaves, Silva et al. [29] determined that the accumulation of trace metals in the first days was low, and due to the residence time of leaves on sediments of 10 days, they suggested that the metal export from the forest was relatively low. They obtained similar results when analyzed the concentration of $\mathrm{Fe}, \mathrm{Zn}$, and $\mathrm{Pb}$ in decomposing leaves in Natal, Brazil. On the other hand, Wen-Jiao, Xiao-Yong, and Peng [30] in a forest of Rhyzophora stylosa in China, concluded that the concentration of heavy metals in residues from floor could be 2-30 times higher than in plant and litterfall, and some metals have low availability in soils due to precipitation in a complex formed with sulfide. Sthevan, Krishnan, and Patterson [31] suggested that soils of $R$. mangle and $A$. germinans have many binding sites that are important for the absorption of metals. They concluded that when the plants absorbed and accumulated heavy metals, the conductive tissues become reduced and decreased the water transportation and growth. Jingchun et al. [32] analyzed the soils of Rhizophora stylosa and concluded that the mobility of $\mathrm{Fe}, \mathrm{Cu}, \mathrm{Cd}$, and $\mathrm{Pb}$ in sediments depend on the chemical form oxidized, binding sites (organic matter, carbonate) sulfide, and the exchangeable sites (weakbound). In sediments of Rhizophora apiculata and Avicennia marina, Kammaruzzaman et al. [33] studied the bioaccumulation of $\mathrm{Pb}$ and $\mathrm{Cu}$ in both species. The concentration factor showed that the heavy metals concentration in root was higher in Avicennia than Rhizophora. It seems that Rhizophora is a genus that is an ion excluding species with an advanced iron plaques mechanism.

L. racemosa (white mangrove)- is considered as a salt excluding species by Lugo [34] and a shade intolerant species by Foroughbakhch et al. [35]. Lacerda et al. [27] suggested that BCF varies under different saline conditions and it is indication of adaptation. Da Souza et al. [36] evaluated the uptake and the translocation of metals in roots and leaves, and the changes in the anatomy of roots of Laguncularia in two estuaries with different grade of pollution. They concluded that $L$. racemosa is a reliable species for monitoring of estuaries impacted by human pollution using the changes in root anatomy.

A. germinans (black mangrove) - is a salt and ion excreting species. It develops in soils with low sulfide, high organic matter and high oxidizing conditions; Lacerda et al. [27] studied the mineral concentration in leaves of $A$. germinans. They concluded that $\mathrm{Cu}$ is bound to organic matter and for this reason it has low availability, the $\mathrm{Zn}$ is biologically controlled, and $\mathrm{Pb}$ is absorbed by leaves from atmospheric deposition. MacFarlane et al. [16] determined BCF in leaves of $A$. germinans, they concluded that mangrove forest is an efficient biochemical barrier to the movement of heavy metals to marine environment. Mellem et al. [13] studied the Translocation Factor (TF) and BCF in Amaranthus dubins, and concluded that in general the heavy metals are transported from soil and accumulated in roots. Similar results were obtained [12] with water Hyacinth plants, where the concentrations of $\mathrm{Cu}, \mathrm{Ni}$, $\mathrm{Zn}$ were 6-20 times higher in roots than shoots. Mac- 
Farlane et al. [16] determined that $\mathrm{Cu}, \mathrm{Zn}, \mathrm{Pb}$ were accumulated in root while $\mathrm{Cu}$ and $\mathrm{Zn}$ showed limited mobility to leaves. The study suggested that increase in enzyme activity and decrease in the photo pigments could be used as sensitive biomarkers of metal stress in A. marina.

Other have analyzed [37] six heavy metals in mangrove sediments of the Red Sea. The BCF indicated that $A$. marina is an efficient plant for bioaccumulation of $\mathrm{Cu}$ and $\mathrm{Cr}$ in the above ground parts. Kumar et al. [38] analyzed the accumulation of $\mathrm{Pb}, \mathrm{Zn}$, and $\mathrm{Cd}$ by A. marina. The order was root $>$ stem $>$ leaf. They considered that $A$. marina is a phytoremediation species for heavy metals. Naidoo et al. [39] assessed the ecophysiological responses of $A v$. marina to heavy metal contamination. The results showed that salt glands contribute to the elimination of trace metals if they were taken up in excess. $\mathrm{Cu}$ and $\mathrm{Zn}$ were excreted by glands. The petroleum in soils and its bioaccumulation in $A$. marina were analyzed by Lotfinasabasl and $\mathrm{Gu}-$ nale [18]. The BCF and TF proved the potential of using this species for phytoremediation to prevent and clean up the petroleum pollution in coast. Lotfinasabasl and Gunale [18] studied six heavy metals in leaves, roots and seedlings of $A$. marina. The BCF's proved the phytoremediation potential for $\mathrm{Fe}, \mathrm{Cu}, \mathrm{Co}, \mathrm{Cd}, \mathrm{Cr}$, and $\mathrm{Ni}$ in areas polluted with industrial and agricultural runoff. The bioaccumulation of $\mathrm{Pb}$ and $\mathrm{Cu}$ was studied in $A$. marina and $R$. apiculata by Kamaruzzamann et al. [33]. The concentrations were higher in $A$. marina in root than bark and leaf. The Concentration Factor showed that accumulation of $\mathrm{Pb}, \mathrm{Cu}$ was higher in $A$. marina than $R$. apiculata

\section{CONCLUSION}

In conclusion, our research in La Esperanza suggests that the three mangrove species ( $A$. germinans, $R$. mangle, and $L$. racemosa) have a synergistic effect to the bioremediation of heavy metals in the three sites analyzed (A, B, C). The results suggest that $A$. germinans has higher phytoremediation conditions than $R$. mangle and L. racemosa. In the near future, studies related with our research such as the heavy metal concentration in root and stem must be made. The chemical mechanisms involved in uptake and exclusion of metals by mangrove species are encouraged to be pursue.

\section{ACKNOWLEDGMENT}

This research was possible with the support of the graduate students Carla Mejias and Luis A. Colón from the School of Environmental Affairs, Universidad Metropolitana, San Juan; and student Melanie De La Rosa from the Universidad del Este, Carolina, PR. The personnel of the School of Environmental Affairs was very helpful in the project. This research was funded by the Southern Research Station of the United States Department of Agriculture-Forest Service, Grant \#: 11DG-11330101-110.

\section{REFERENCES}

1. Gould WA, Quiñones M, Solórzano M et al (2011) Protected natural areas of Puerto Rico. 1:24,000. IITFrmap-02.Río Piedras: US Department Of Agriculture, Forest Service, International Institute Of Tropical Forestry.

2. DNER, Department of Natural and Environmental Resources of P.R. (2005) Puerto Rico's Comprehensive Wildlife Conservation Strategy https://griffingroups.com/.

3. Bauzá-Ortega J (2013) La ciénaga las Cucharillas: un tesoro ecológico en el estuario de la bahía de San Juan. Perspectivas En Asuntos Ambientales. 2: 18-25.

4. Miller GL, Lugo AE (2009) General Technical Report (IITF-GTR-35) San Juan, PR: U.S. Department of Agriculture, Forest Service, International Institute of Tropical Forestry.

5. Waite R, Burke L, Gray E et al (2014) Coastal Capital: Ecosystem Valuation for Decision Making in the Caribbean. Washington, DC: World Resources Institute. http://www.wri.org/.

6. González-Mendoza D, Juárez OG, Cervantes Díaz L (2008) Los elementos potencialmente tóxicos en las plantas de manglar: una revisión de los mecanismos de tolerancia involucrados. Interciencia: 33.

7. Maisto G, Manzo S, De Nicola F et al (2011) Assessment of the effects of $\mathrm{Cr}, \mathrm{Cu}, \mathrm{Ni}$ and $\mathrm{Pb}$ soil contamination by ecotoxicological tests. Journal of Environmental Monitoring 13: 3049-3056.

8. Lombardo A, Rocaglioni A, Bonani E et al (2010) Assessment and Validation of the CAESAR predictive model for biococentration factor in fish. Chemistry Central Journal 4(1) doi: 10.1186/1752-153X-4-S1-S1.

9. Mejías CL, Musa JC, Otero J (2013) Exploratory evaluation of retranslocation and bioconcentration efficiency of heavy metals in three species of mangrove at Las Cucharillas Marsh, Puerto Rico. The Journal of Tropical Life Sciences 3: 14-22.

10. Fernandes J, Henriques FS (1991) Biochemical, physiological, and structural effects of excess copper in plants. The Botanical Review 57: 246-273.

11. Science Communication Unit (SCU), University of the West of England, Bristol (2013) Science for Environment 
Policy In-depth Report: Soil Contamination: Impacts on Human Health. Report produced for the European Commission DG Environment. http://ec.europa.eu/.

12. Hammad DM (2011) Cu, Ni and Zn Phytoremediation and Translocation by Water Hyacinth Plant at Different Aquatic Environments. Australian journal of basic and applied sciences 5: 11-22.

13. Mellem J, Baijnath H, Odhav B (2009) Translocation and accumulation of $\mathrm{Cr}, \mathrm{Hg}, \mathrm{As}, \mathrm{Pb}, \mathrm{Cu}$ and $\mathrm{Ni}$ by Amarranthus dubius (Amaranthaceae) from contaminated sites. Journal of Environmental Science and Health Part A: Toxic/Hazardous Substances and Environmental Engineering. 44: 568-575.

14. Drexler J, Fisher N, Henningsen G et al (2003) Issue paper on the bioavailability and bioaccumulation of. US EPA https://archive.epa.gov/.

15. Birch GF, Olmos MA (2008) Sediment-bound heavy metals as indicators of human influence and biological risk in coastal water bodies. International council for the exploration of the sea. Journal Of Marine Science Oxford Journals 65:1407-1413.

16. Otero E (2011) Estuarine Environmental Indicators for the San Juan Bay Estuary: Assessment of Sediment and Fish Tissue Contaminants. The San Juan Bay Estuary Program, USEPA, Region 2.

17. Gupta S, Chakrabarti SK (2013) Mangroves-a potential phyto-remediator and useful bio-indicator against heavy metal toxicity. International Journal Of Bio-Resource \& Stress Management. 4: 322-327.

18. Lotfinasabasl S, Gunale VR (2012) Studies on heavy metals bioaccumulation potential of mangrove species, Avicennia marina. International Journal of Engineering Science and Technology. 4: 4411-4421.

19. Tao LW, Cheng NY, Xing ZQ (2013) Uptake of Heavy Metals by Trees: Prospects for Phytoremediation. Materials Science Forum. 743: 768-781.

20. MacFarlane GR (2002) Leaf biochemical parameters in Avicennia marina as potential biomarkers of heavy metals stress in estuarine ecosystems. Marine Pollution Bulletin. 44: 244-256.

21. Azevedo R, Rodriguez E (2012) Phytotoxicity of mercury in plants: a review. Journal of Botany. DOI:10.1155/2012/848614

22. Machado W, Gueiros BB, Lisboa-Filho SD, Lacerda LD (2005) Trace metal in mangrove seedlings: role of iron plaque formation. Wetlands Ecology and Management. 13: 199-206.

23. Pi N, Tam NFY, Wong MH (2011) Formation of iron plaque on mangrove roots receiving waste water and its role in immobilization of wastewater-borne pollutants. Marine Pollution Bulletin. 63: 402-411.
24. Lin P, Wang W (2001) Changes in the leaf composition, leaf mass and leaf area during leaf senescence in three species of mangroves. Ecological Engineering. 16: 415-424.

25. Chen M, Ma LQ, Harris WG (1999) Baseline concentrations of 15 trace elements in Florida surface soils. Journal Of Environmental Quality. 28: 1173-1181.

26. Conde C, Oliveira-Rodriguez F, Orgler de Moura D (1997) Long - Term Assessment of oil Spill in a Mangrove Forest in Sao Paulo, Brazil. Mangrove Ecosystem Studies in Latin America and Africa, UNESCO.

27. Lacerda LD, Carvalho CE, Tanizaki KF et al (1993) The biogeochemistry and trace metals distribution of mangroves rhizospheres. Biotropica. 25: 252-257.

28. Machado W, Silva-Filho EV, Oliveira RR, Lacerda LD (2002) Trace metal retention in mangrove ecosystems in Guanabara Bay, SE Brazil. Marine Pollution Bulletin. 44: 1277-1280.

29. Silva C, Silva A, Oliveira S (2006) Concentration stock and transport rate of heavy metals in a tropical red mangrove, Natal, Brazil. Marine Chemistry. 99: 2-11.

30. Wen JZ, Xiao YC, Peng L (1997) Accumulation and biological cycling of heavy metal elements in Rhizophora stylosa mangroves in Yingluo Bay, China. Marine Ecology Progress Series. 159: 293-301.

31. Sthevan R, Krishnan TSR, Patterson J (2011) Preliminary survey on the heavy metal pollution in Punnakayal Estuary of Tuticorin Coast, Tamil Nadu, India. Global Journal of Environmental Research. 5: 89-96.

32. Jingchun L, Chongling $Y$, Macnair $M$ et al (2006) Distribution and Speciation of Some Metals in Mangrove Sediments from Jiulong River Estuary, People's Republic of China. Bulletin Environmental Contamination and Toxicology 76: 815-822.

33. Kammaruzzaman BY, Rina SMZ, Akbar JB, Siti WA (2012) Accumulation and distribution of Lead and Copper in Avicennia marina and Rhizophora apiculata from Balok Mangrove Forest, Pahang, Malaysia. Sains Malaysiana. 20: 555-560.

34. Lugo AE (1999) Mangrove Forests: A tough system to invade but an easy one to rehabilitate. Marine Pollution Bulletin. 37: 427-430.

35. Foroughbakhch $\mathrm{R}$, Caspedes A, Alvarado M, Nunez A, Bahi M (2004) Aspectos ecológicos de los manglares y su potencial como fitorremediadores en el golfo de Mexico. Ciencia UANL. 7.

36. Da Souza I, Marques Bonomo M, Morozesk $\mathrm{M}$ et al (2014) Adaptive plasticity of Laguncularia racemosa in response to different environmental conditions: integrating chemical and biological data by chemometrics. Ecotoxicology. 23: 335-348. 
37. Usman ARA, Alkredaa RS, Al-Wabel MI (2013) Heavy metal contamination in sediments and mangroves from the coast of Res Sea: Avicennia marina as potential metal bioaccumulator. Ecotoxicology and Environmental Safety. 97: 263-270.

38. Kumar NJI, Sajish PR, Kumar RN et al (2011) Bioaccumulation of Lead, Zinc and Cadmium in Avicennia marina Mangrove Ecosystem near Namada Estuary in Vamleshwar, West Coast of Gujarat, India. Journal of Int. Environmental Application and Science. 6: 8-13.

39. Naidoo G, Hiralal T, Naidoo Y (2014) Ecophysiological Responses of the Mangrove Avicenna marina Trace Metal Contamination. Flora-Morphology Functional Ecology of Plants. 209: 63-72.

40. Huang GY, Wang YS (2010) Expression and characterization analysis of type 2 metallothionein from grey mangrove species (Avicennia marina) in response to metal stress. Aquatic Toxicology. 99: 86-92.

41. Miao S, Chen G, De Laune R, Jugsujinda A (2007) Partitioning and removal of $\mathrm{Cd}$ and $\mathrm{Mn}$ using a simulated mangrove wastewater treatment system. Journal of Environmental Science and Health. 42: 405-411.

42. Parvaresh H, Abedi Z, Farshchi P et al (2011)
Bioavailability and concentration of heavy metals in the sediments and leaves of grey mangrove, Avicennia marina in Sirik Azini Creek, Iran. Biological Trace Element Research. 143: 1121-1130.

43. Rachman M, Rahman M, Chongling Y, Islam K (2011) Accumulation, distribution and toxicological effects induced by Cadmium on the development of mangrove plant Kandelia candel (L). Contemporary Problems of Ecology. 4: 133-139.

44. Silva C, Lacerda L, Ovalle A, Rezende C (1998) The dynamics of heavy metals through litterfall and decomposition in a red mangrove forest. Mangrove and Salt Marshes. 2: 149-157.

45. Yuhong L, Atagana HI, Jingchun L et al (2013) cDNA sequence encoding metallothionein protein from Aegiceras corniculatum and its gene expression induced by $\mathrm{Pb} 2+$ and $\mathrm{Cd} 2+$ stresses. Environmental Monitoring Assessment. 185: 10201-10208.

46. Zhang F, Wang Y, Lou Z, Dong J (2007) Effect of heavy metal stress on antioxidative enzymes and lipid peroxidation in leaves and roots of two mangrove plant seedlings (Kandalia Candel and Brugueira gymnorrhiza). Chemosphere. 67: 44-50. 